\title{
Screening of some Sumatran medicinal plants and selected secondary metabolites for their cytotoxic potential against MCF-7 and HSC-3 cell lines
}

\author{
HUSNUNNISA $^{1} \mathbb{D}$, Friardi ISMED ${ }^{1} \mathbb{D}$, Muhammad TAHER ${ }^{2} \mathbb{D}$, , Solachuddin Jauhari Arief ICHWAN ${ }^{3}$ \\ (D), Amri BAKHTIAR 1 (D), Dayar ARBAIN 1 * (D) \\ 1 Faculty of Pharmacy/Sumatran Biota Laboratory, Andalas University, Padang, 25163, West Sumatra, Indonesia. \\ 2 Department of Pharmaceutical Technology, Faculty of Pharmacy, International Islamic University Malaysia, 25200, \\ Kuantan, Pahang, Malaysia. \\ 3 Department of Basic Medical Sciences, Faculty of Dentistry, International Islamic University Malaysia, 25200, \\ Kuantan, Pahang, Malaysia. \\ * Corresponding Author. E-mail: dayararbain@gmail.com; d.arbain@phar.unand.ac.id (D.A.); Tel. +62 811666866.
}

Received: 03 October 2018 / Revised: 09 February 2019 / Accepted: 24 February 2019

\begin{abstract}
In continuation of our study of Sumatran plants and bioactivities of their constituents particularly their cytotoxic activities, we re-extracted lichen Stereocaulon graminosum Schaer (Stereocaulaceae), and isolated atranorin (1) and stictic acid (4). These isolated compounds have been tested for their cytotoxic activities against human breast adenocarcinoma cancer cell (MCF-7) and human oral squamous carcinoma cancer cell (HSC-3) using MTT assay with a slight modification. Some methanolic extracts of the leaves of Elephantopus scaber, Piper betle, Andrographis paniculata, rhizomes of Boesenbergia pandurata, Alpinia galanga, Kaempferia galanga and isolated compounds; ethyl haematommate (2), olivatolic acid (3), deoxyelephantopin (5), andrographolide (6), hydroxychavicol (7), eugenol (8), curcumin (9), pinostrobin (10), pinocembrin (11), alpinetin (12), a-mangostin (13), angiopteroside (14), and stevioside (15) from Sumatran traditional medicinal plants have also been tested.
\end{abstract}

KEYWORDS: Sumatran plants; isolated compounds; cytotoxic; MCF-7; HSC-3.

\section{INTRODUCTION}

Cancer is a major cause of health problem in Indonesia. Breast cancer, cervical cancer, ovarian cancer, and colorectal cancer occur as the leading cancers among females in 2005-2007 in the City of Jakarta [1]. Breast cancer is the primary cause of cancer-related deaths among women, of which 1.67 million $(25.2 \%)$ of new cases and 521,907 (14.7\%) deaths in the world [2]. In Indonesia breast cancer and oral cancer is predominantly diagnosed in the advanced stages $[3,4]$.

Sumatra as the fifth largest island in the word like other islands of Indonesia is very rich with variety of tropical plants, some of them are known for treating various diseases including cancer such as Curcuma, Kaempferia, and Zingiber [5].

Based on our previous study on the chemistry of Sumatran Plants [6, 7], some ecotype of Indonesian plants might give different constituents, therefore we reinvestigated their bioactivities in this study. Previous cytotoxic studies of extracts and isolates of Sumatran medicinal plants against cancer are still very limited despite the frequent use of some of those plants as complementary to those conventional cancer drugs including to minimize the harsh side effects of chemotherapy.

In continuation of our study of Sumatran plants and bioactivities of their constituents [6] particularly to validate their use for complementary of treating cancer, we re-extracted lichen Stereocaulon graminosum [8] to obtain atranorin (1), and stictic acid (4). These two compounds together with some extracts of the leaves of Elephantopus scaber, Piper betle, Andrographis paniculata, rhizomes of Boesenbergia pandurata, Alpinia galanga, Kaempferia galanga and previously isolated compounds; ethyl haematommate (2), olivatolic acid (3), deoxyelephantopin (5), andrographolide (6), hydroxychavicol (7), eugenol (8), curcumin (9), pinostrobin (10), pinocembrin (11), alpinetin (12), a-mangostin (13), angiopteroside (14), and stevioside (15) (figure 1) have also been tested for their cytotoxic activities against MCF-7 and HSC-3 cell lines.

How to cite this article: Husnunnisa, Ismed F, Taher M, Ichwan SJA, Bakhtiar A, Arbain D. Screening of some Sumatran medicinal plants and selected secondary metabolites for their cytotoxic potential against MCF-7 and HSC-3 cell lines. J Res Pharm. 2019; 23(4): 770-776. 
The cytotoxicity study of these compounds and extracts against human breast adenocarcinoma cancer cells (MCF-7) and human oral squamous carcinoma cancer cells (HSC-3) was carried out following the method of MTT assay (3-(4,5-dimethylthiazol-2-yl)-2,5-diphenyltetrazolium bromide) [9] with a slight modification [10]. Due to some limitations, the cytotoxicity of the extracts of A. paniculata, E. scaber, P. betle, B. pandurata, A. galanga, K. galanga could only be done against human breast adenocarcinoma cancer cell (MCF-7).<smiles>Cc1cc(OC(=O)c2c(C)cc(O)c(C=O)c2O)c(C)c(O)c1C(=O)O</smiles><smiles>CCOC(=O)c1c(C)cc(O)c(C=O)c1O</smiles>

2<smiles>C=CCc1ccc(O)c(O)c1</smiles><smiles>CCCc1cc(O)cc(O)c1C(=O)O</smiles><smiles>COc1cc(C)c2c(c1C)Oc1c(OC)c(C)c(O)c3c1OC(O)C3OC2=O</smiles>

4

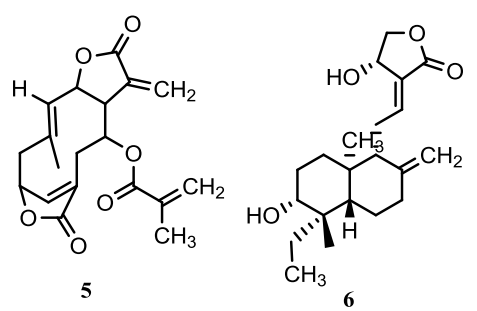<smiles>C=CCc1ccc(O)c(OC)c1</smiles><smiles>COc1cc(/C=C/C(=O)CC(=O)/C=C/c2ccc(O)c(OC)c2)ccc1O</smiles><smiles>COc1cc(O)c2c(c1)OC(c1ccccc1)CC2=O</smiles><smiles>O=C1CC(c2ccccc2)Oc2cc(O)cc(O)c21</smiles>

11<smiles>COc1cc(O)cc2c1C(=O)CC(c1ccccc1)O2</smiles><smiles>COc1c(O)cc2oc3cc(O)c(CC=C(C)C)c(O)c3c(=O)c2c1O</smiles>

12<smiles>C[C@@H]1OC(=O)C=C[C@@H]1Cl</smiles>

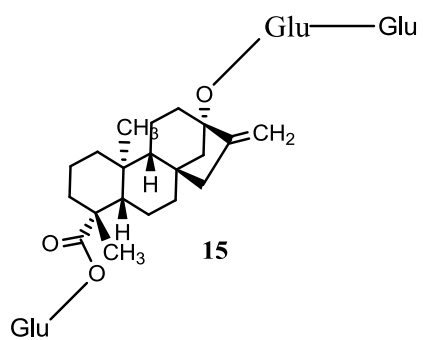

Figure 1. Structures of selected compounds tested in the cytotoxic activity.

\section{RESULTS}

In our previous isolation work on S. graminosum [8] we isolated ethyl haematommate (2), and from Stereocaulon montagneanum (Stereocaulaceae) we found stictic acid (4) [11], but not enough to continue to work on their cytotoxic activities. In order to obtain enough secondary metabolites from this species more extraction and isolation work was carried out and due to limited availability of sample S. graminosum only atranorin and stictic acid could be isolated and characterized.

From table 1 and figure 2, out of 15 compounds tested for their cytotoxic activities against HSC-3 cells only 3 compounds showed high-moderate activity with $\mathrm{IC}_{50}<100 \mu \mathrm{M}$; alpinetin, stictic acid, pinostrobin, with IC $_{50}$ values of $12.76 \mu \mathrm{M}, 39.50 \mu \mathrm{M}$, and $81.54 \mu \mathrm{M}$ respectively, while the positive control cisplatin gave IC $_{50}$ value $=20 \mu \mathrm{M}$.

The results of cytotoxic activity on MCF-7 cells showed that out of 6 extracts tested there were 3 extracts showed moderate activity E. scaber, B. pandurata, and A. paniculata with $\mathrm{IC}_{50}$ values of $47.36 \mu \mathrm{g} / \mathrm{mL}, 47.78$ $\mu \mathrm{g} / \mathrm{mL}$, and $60.41 \mu \mathrm{g} / \mathrm{mL}$, respectively. Out of 15 tested isolated compounds, there were 4 compounds that have high-moderate activity against MCF-7 cells with IC 50 values $<100 \mu \mathrm{M}$; curcumin, a-mangostin, deoxyelephantopin, and stictic acid, with $\mathrm{IC}_{50}$ values of $12.65 \mu \mathrm{M}, 34.35 \mu \mathrm{M}, 64.29 \mu \mathrm{M}$, and $95.78 \mu \mathrm{M}$, respectively. 
Table 1. IC 50 values of extracts, isolated compounds and positive control against MCF-7 and HSC-3 cell lines $\mathrm{a}^{*}$

\begin{tabular}{lccc}
\hline Isolated Compounds / Extracts & & \multicolumn{3}{c}{ IC $_{\mathbf{5 0}}$} \\
\cline { 3 - 4 } & & MCF-7 & HSC-3 \\
\hline Elephantopus scaber & E1 & 47.36 & - \\
Piper betle & E2 & 15774.25 & - \\
Andrographis paniculata & E3 & 60.41 & - \\
Boesenbergia pandurata, & E4 & 47.78 & - \\
Alpinia galangal & E5 & 416.47 & - \\
Kaemferia galanga & E6 & 693.99 & - \\
Atranorin & 1 & 208.20 & 474.08 \\
Stictic acid & 2 & 95.78 & 39.50 \\
Ethyl haematommate & 3 & 186.60 & 203.29 \\
Deoxyelephantopin & 4 & 64.29 & n.d \\
Hydroxychavicol & 5 & 320.29 & 1164.55 \\
Andrographolide & 6 & 138.87 & .d \\
Pinostrobin & 7 & 1041.64 & 81.54 \\
Pinocembrin & 8 & 247.14 & n.d \\
Alpinetin & 9 & 572.58 & 12.76 \\
Eugenol & 10 & 211.56 & 38549.6 \\
Curcumin & 11 & 12.65 & 208.72 \\
a-Mangostin & 12 & 34.35 & n.d \\
Angiopteroside & 13 & 2915.06 & n.d \\
Olivatolic acid & 14 & 406 & 448.59 \\
Stevioside & 15 & 1501.40 & 376.65 \\
Doxorubicin & & 6.21 & - \\
Cisplatin & & - & 20 \\
\hline
\end{tabular}

a $\mathrm{IC}_{50}$ values of extracts in $\mu \mathrm{g} / \mathrm{mL}, \mathrm{IC}_{50}$ values of isolated compounds in $\mu \mathrm{M}$.

n.d $=$ not determined

*The tests were done in triplicate. - not tested

\section{DISCUSSION}

Lichens have been used in traditional medicine such as Traditional Indian Medicine (TIM), Traditional Chinese Medicine (TCM), Homeopathic and Western Herbal Medicine, to treat various diseases like arthritis, alopecia, constipation, kidney diseases, leprosy. The medicinal agents of lichens are noticed due to the existence of secondary compounds i.e. usnic acid, atranorin and stictic acid. Lichens constituent's bioactivity study have also revealed antimicrobial, antitumor and immunomodulator activity [12]. In this study, HSC-3 cell lines looked more sensitive toward the constituents of Lichen S. graminosum stictic acid than MCF-7 with IC 5039.50 and $95.78 \mu \mathrm{M}$-respectively. Activity of stictic acid toward MCF-7 has been done previously but there was no $\mathrm{IC}_{50}$ reported [13]. It seems from this study that the constituents of Lichens need more attention to explore their activity against other cancer cell lines further.

Our previous work indicated that $B$. pandurata of different ecotype gave different chemical constituents. Sumatran ecotype of B. pandurata with its major constituent pinostrobin (10), pinocembrin (11), alpinetin (12) [7] has been traditionally used by Sumatran people for treatment of diverse diseases. Previous study showed various activities of extract and fractions [14]. In this study methanolic extract was active against MCF-7 with $\mathrm{IC}_{50} 47.78 \mu \mathrm{g} / \mathrm{mL}$. There was no report on the activity of pinostrobin and alpinetin toward HSC-3, we found their $\mathrm{IC}_{50}$ were 81.54 and $12.76 \mu \mathrm{M}$ respectively. This work indicated very weak activity of pinostrobin $\left(\mathrm{IC}_{50}\right.$ $>100 \mu \mathrm{M})$ and alpinetin $\left(\mathrm{IC}_{50}>100 \mu \mathrm{M}\right)$ against MCF-7 which were similar to previous reported work [15; 16; 17].

C. longa beside as a cooking spice and natural coloring matter in food, it is also used as an antiinflammatory, antioxidant, hepatoprotective, chemopreventive and chemotherapy. Curcumin as its major compound was found active as cytotoxic agent toward multiple myeloma, pancreatic cancer, myelodysplastic syndromes, colon cancer and radioprotective properties. These major constituents perform in multidrugresistant breast cancer, prostate cancer and colon cancer [18]. Curcumin can prevent metastasis by suppressing adhesion of cancer cells [19]. In this study, we found curcumin (9) gave strong activity against MCF-7 with $\mathrm{IC}_{50} 12.65 \mu \mathrm{M}$. 
a-Mangostin as a major constituent of the pericarp of G. mangostana L. has been reported to have cytotoxic activities against colorectal cancer cells (HCT 116), hepatocellular carcinoma cells (HepG2) and breast adenocarcinoma cells (MCF-7) with $\mathrm{IC}_{50} 68.9 \pm 2.9 \mu \mathrm{M}, 53.8 \pm 3.2 \mu \mathrm{M}$, and $51.5 \pm 2.8 \mu \mathrm{M}$, respectively [20]. a-Mangostin (13) in our study gave activity against MCF-7 with $\mathrm{IC}_{50} 34.35 \mu \mathrm{M}$.

A

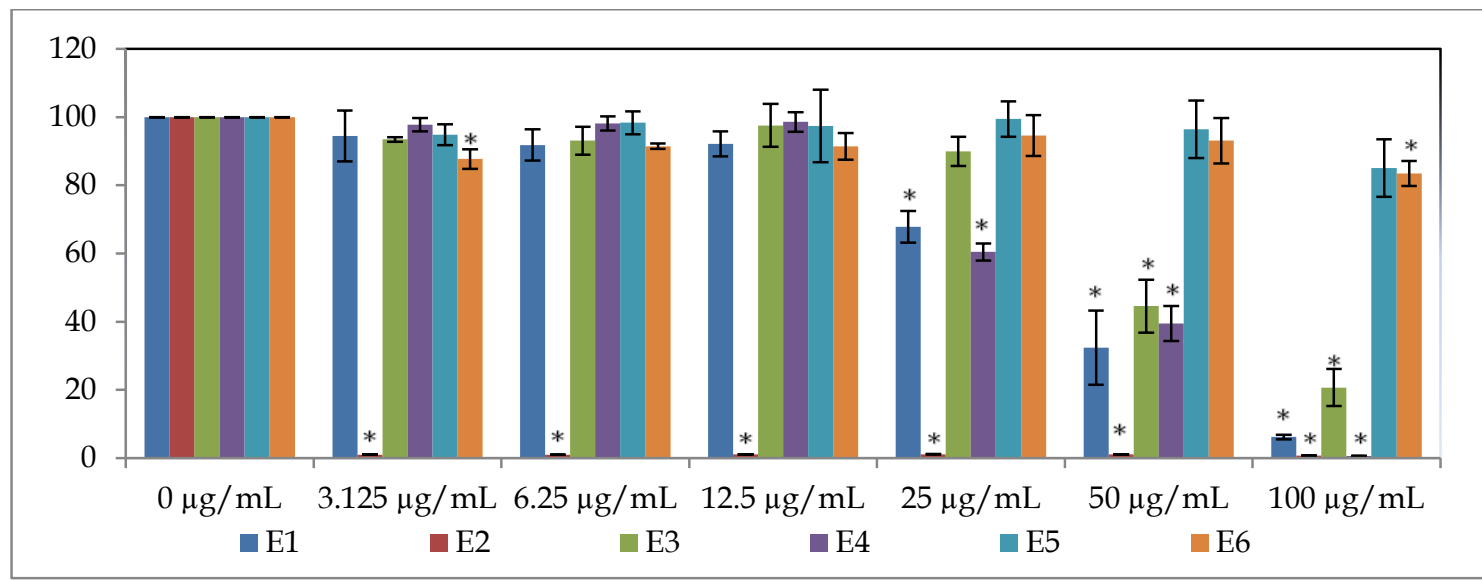

B

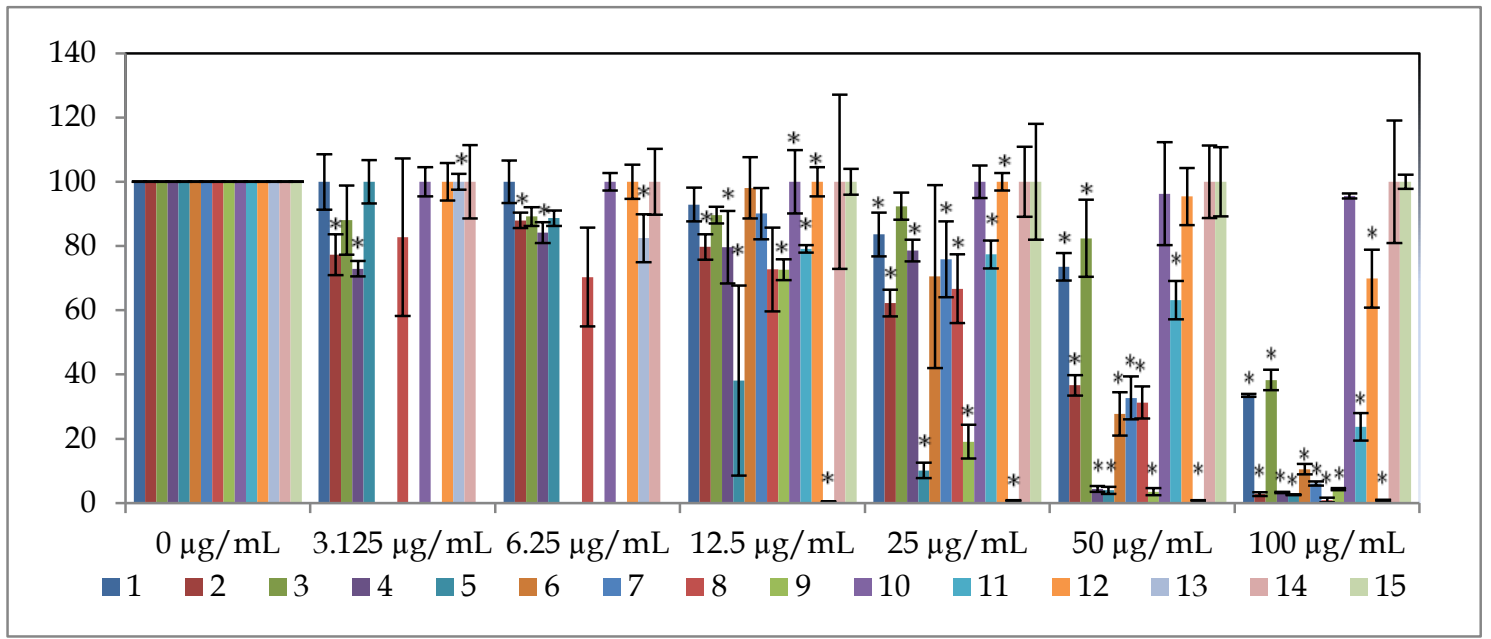

C

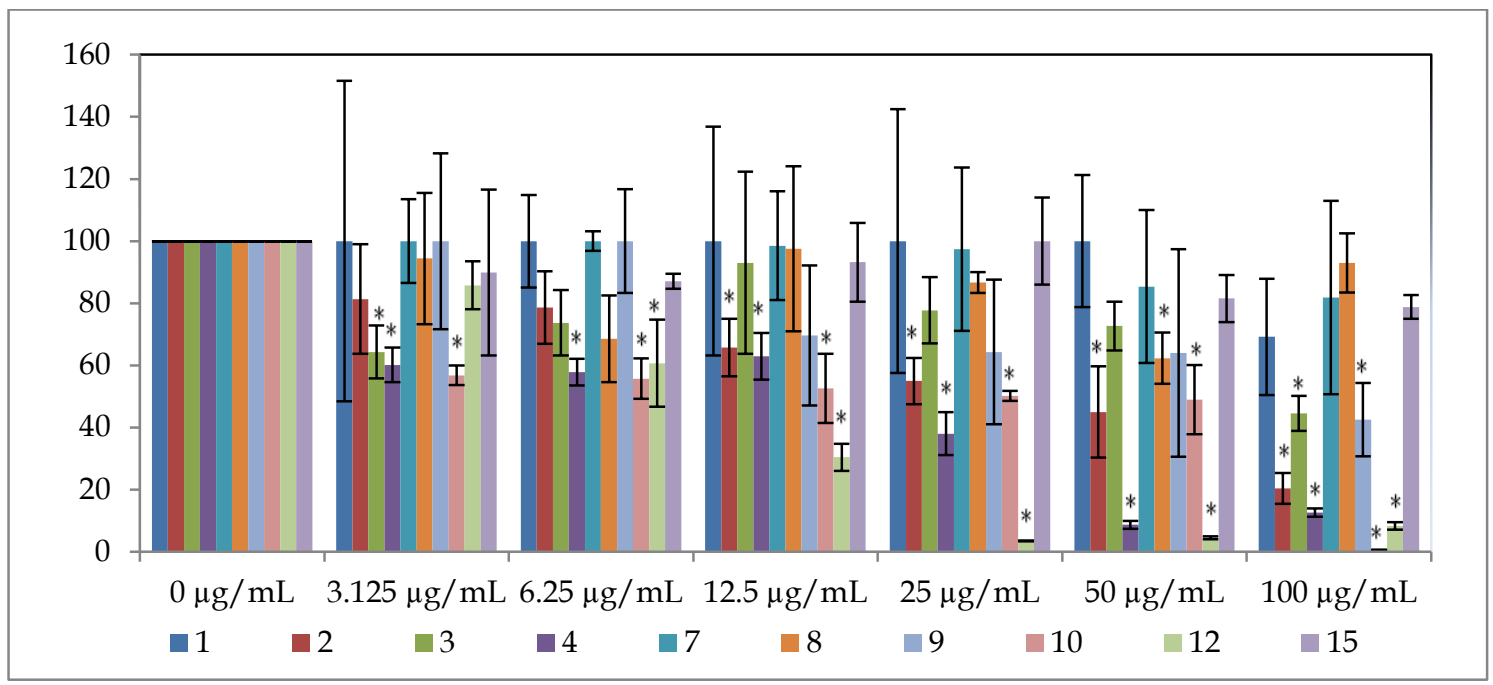

Figure 2. In Vitro Cytotoxicity Assay of some extracts and isolated compounds of Sumatran medicinal Plants using the modified MTT Method. A. Some extracts against MCF-7 cells $(\mathrm{E} 1=$ E. scaber, $\mathrm{E} 2=$ P. betle, $\mathrm{E} 3=$ A. paniculata, $\mathrm{E} 4=$ B . pandurata, $\mathrm{E} 5=$ A. galanga, $\mathrm{E} 6=\mathrm{K}$. galanga B. Compounds 1-15 against MCF-7 cells C. Compounds 1-15 against HSC-3 cells. The results represent the mean \pm standard error of triplicate experiments. ${ }^{*}(P<0.05)$ indicate significant difference from untreated control. 


\section{CONCLUSION}

The three extracts tested for their cytotoxic activities against MCF-7 cells showed significant effects. $E$. scaber extract showed the strongest activity against MCF-7 cells with $\mathrm{IC}_{50}=47.36 \mu \mathrm{g} / \mathrm{mL}$. For isolated compounds, curcumin showed the strongest activity against MCF-7 cells with the value of $\mathrm{IC}_{50}=12.65 \mu \mathrm{M}$. Whereas towards HSC-3 cells, alpinetin showed the strongest activity with the value of $\mathrm{IC}_{50}=12.76 \mu \mathrm{M}$.

\section{MATERIALS AND METHODS}

All solvents were analytical grade or distilled before being used. TLC was carried out using silica gel $60 \mathrm{~F}_{254}$ (Merck) and visualized under UV light $(254 \mathrm{~nm})$. Column chromatography was performed on silica gel 60 (0.063-0.200 nm) (Merck). Melting points were measured by using a Fisher - John Melting Point Apparatus, UV Spectra were obtained in MeOH using a UV-Vis Spectrophotometry (Shimadzu Pharmaspec $1700^{\circledR}$ ), while IR spectra were obtained on an Infrared Spectrometry (Perkin Elmer ${ }^{\circledR}$ ), The nuclear magnetic resonance (NMR) spectra were obtained on a Bruker Avance II at 500 and $125 \mathrm{MHz}$ ).

\subsection{Plant material}

Lichen S. graminosum Schaer was collected in February 2016 on the rocks near the summit (2300) of Mount Talang (2597 masl), West Sumatra, Indonesia. Plant specimen was identified by Dr. Friardi Ismed based on previous identification by Dr. Harrie Sipman, Mycology Laboratory, Universite de Rennes and Berlin Museum Botanical. Other plant samples to prepare extracts were collected around the city of Padang in November, 2017 and identified by Dr. Nurainas from Herbarium of Andalas University (ANDA); B. pandurata (identification no. 093), K. galanga (no. 086), E. scaber (no. 327), P. betle (no. 0108), A. paniculata (no. 030), A. galanga (cf. Fitri et al. collection number 09).

Some isolated compounds from Sumatran medicinal plants were available in our laboratory from previous work; ethyl haematommate from S. graminosum [8], eugenol from Syzygium aromaticum, hydroxychavicol from Piper betle, and curcumin from Curcuma xanthorrhiza [21], pinostrobin, pinocembrin and alpinetin from B. pandurata [7]. a-mangostin from Garcinia mangostana and andrographolide from Andrographis paniculata [22], deoxyelephantopin from E. scaber [23], angiopteroside from Angiopteris evecta [24], olivatolic acid from Cetrelia sanguinea [25], stevioside from Stevia rebaudiana [26].

\subsection{Chemistry}

\subsubsection{Preparation of plant extracts}

Fresh leaves of E. scaber, P. betle, A. paniculata, and rhizomes B. pandurata, A. galanga, K. galanga (100 g) were maserated thrice with methanol then evaporated in vacuo to give thick extract 3.04, 5.59, 12.19, 3.35, 0.75, 1.79 g respectively.

\subsubsection{Isolation of major constituents of S. graminosum}

The sample used was whole thallus of lichen S. graminosum, which was sorted, dried, chopped, blended to obtain lichen powder $(132 \mathrm{~g})$ and macerated in turn with n-hexane, ethyl acetate (EtOAc) then acetone ( $3 \times 3$ days each). The combined hexane extracts filtered, evaporated in vacuo and recrytallized from EtOAc-hexane to give atranorin $(15 \mathrm{mg})$, The combined EtOAc extracts was filtered, evaporated in vacuo to give solid residue $(2.16 \mathrm{~g})$. This was chromatographed on silica gel and eluted with toluene, EtOAc, and formic acid $(70: 25: 5)$. Fractions that gave similar behavior on TLC were combined, evaporated and recrystallized from EtOAchexane to give atranorin (1) $(65 \mathrm{mg})$ and stictic acid (4) $(37 \mathrm{mg})$. Spectral data of these two compounds were very similar to that of references.

Aceton extracts were combined then filtered, evaporated in vacuo to give solid residue $(1.74 \mathrm{~g})$. This thick residue was chromatographed on silica gel, eluted with toluene, EtOAc, and formic acid $(70: 25: 5)$ to give fractions. The fractions that gave similar behavior on TLC were combined, evaporated and recrystallized to give atranorin $(30 \mathrm{mg})$ and stictic acid $(20 \mathrm{mg})$.

Atranorin (1) - colorless needles; $\mathrm{mp} 191-192^{\circ} \mathrm{C}$ (undepressed in admixture with reference compound; Spectral data were also identical to that of reference previosly isolated from Stereocaulon halei [27].

Stictic acid (4) - colorless needles; $\mathrm{mp} 215-228{ }^{\circ} \mathrm{C}$ (dec) (undepressed in admixture with reference compound. Spectral data were also identical to that of reference previously isolated from S. montagneanum [11]. 


\subsection{Cytotoxic activity}

Two cancer cell lines were used in this study as a pre-screen: MCF-7 and HSC-3 cancer cell lines which were provided by Prof. Masa-Aki Ikeda of Tokyo Medical and Dental University, Tokyo. Cells cultured in DMEM medium were purchased from GIBCO (Invitrogen Corporation, USA), supplemented with foetal bovine serum (FBS), $200 \mathrm{U} / \mathrm{mL}$ of penicillin and $200 \mu \mathrm{g} / \mathrm{mL}$ of streptomycin, at $37^{\circ} \mathrm{C}$ in an atmosphere of $5 \%$ $\mathrm{CO}_{2}$. MTT (3-(4,5-dimethylthiazol-2-yl)-2,5-diphenyltetrazolium bromide) was purchased from Invitrogen (USA), dissolved in sterilized Phosphate Buffer Saline (PBS) at $5 \mathrm{mg} / \mathrm{mL}$ and filtered to remove a small amount of insoluble residue present in some batches of MTT. At the times indicated below, stock MTT solution was added to all wells of an assay, and plates were incubated at $37^{\circ} \mathrm{C}$ for $4 \mathrm{~h}$. DMSO $100 \mu \mathrm{L}$ was added to all wells and mixed thoroughly to dissolve the formazan crystals. After a few minutes at room temperature to ensure that all crystals were dissolved, the plates were read on a Dynatech MR5000 Microplate reader, using a test wavelength of $570 \mathrm{~nm}$ and reference wavelength at $630 \mathrm{~nm}$.

\subsection{Data analysis}

The data were presented in the form of means \pm standard error (SE). Statistical significance was calculated using One-Way ANOVA coupled with Dunnett's t-tests and followed by post hoc test, with $p<0.05$ were considered significant.

Acknowledgements: We gratefully acknowledged the Competency Grant 2015-2017 and 2018 DP2M-DIKTI - The Ministry of Research, Technology and Higher Education of the Republic of Indonesia to DA. We thank The Ministry of Health of the Republic of Indonesia for BBO and BBOT Project and for using Indonesian Herbal Pharmacopoeia markers, to Dr. Nurainas from Andalas University Herbarium (ANDA) for identification of the plant specimens and Professor Hamburger from the University of Basel for NMR spectra of compound 1 and 4.

Author contributions: Concept - F.I., D.A.; Design - F.I., M.T., S.J.A.I., A.B., D.A.; Supervision - F.I., M.T., S.J.A.I., A.B., D.A.; Materials - F.I., M.T., S.J.A.I., D.A.; Data Collection and/or Processing - H., F.I., M.T., D.A.; Analysis and/or Interpretation - H., F.I., M.T., D.A.; Literature Search - H., F.I., M.T., D.A.; Writing - H., F.I., M.T., D.A.; Critical Reviews - H., F.I., M.T., S.J.A.I., A.B., D.A.

Conflict of interest statement: The authors declare no conflict of interest.

\section{REFERENCES}

[1] Wahidin M, Noviani R, Hermawan S, Andriani V, Ardian A, Djarir H. Population-based cancer registration in Indonesia. Asian Pac J Cancer Prev. 2012; 13: 1709-1710. [CrossRef]

[2] Ferlay J, Soerjomataram I, Dikshit R, Eser S, Mathers C, Rebelo M, Parkin DM, Forman D, Bray F. Cancer incidence and mortality worldwide: Sources, methods and major patterns in GLOBOCAN 2012. Int J Cancer Suppl. 2015; 136: E359-E386. [CrossRef]

[3] Ng CH, Phaty NB, Taib NA, Teh YC, Mun KS, Amiruddin A, Evlina S, Rhodes A, Yip CH. Comparison of breast cancer in Indonesia and Malaysia - A Clinico-pathological study between Dharmais Cancer Centre Jakarta and University Malaya Medical Centre, Kuala Lumpur. Asian Pac J Cancer Prev. 2011; 12: 2943-2946.

[4] Sutandyo N, Ramli R, Sari L, Soeis DS. Profile and survival of tongue cancer patients in “Dharmais" Cancer Hospital, Jakarta. Asian Pac J Cancer Prev. 2014; 15(5): 1971-1975. [CrossRef]

[5] Elfahmi, Woerdenbag hj, kayser o. jamu: indonesian traditional herbal medicine towards rational Phytopharmacological use. J Herbal Med. 2014; 69: 1-23. [CrossRef]

[6] Arbain D. Inventory, constituents and conservation of biologically important Sumatran plants. Nat Prod Commun. 2012; 7(6): 799-806

[7] Ismed F, Bakhtiar A. 2017. Production of Ellagic Acid, Panduratin, and 20-hydroxyecdyson as Marker of Indonesian Traditional Medicinal Plants, Research Report, Andalas University, Department of Health Republic of Indonesia.

[8] Ismed F, Arifa N, Zaini E, Bakhtiar A, Umeda D, Putra OD, Yonemochi. Ethyl Haematommate from Stereocaulon graminosum Schaer : Isolation and crystal structure. Nat Prod Sci. 2018; 24(2): 115-118. [CrossRef]

[9] Mosmann T. Rapid colorimetric assay for cellular growth and survival: Application to proliferation and cytotoxic assays. J Immunol Methods. 1983; 65(1-2): 55-63. 
[10] Al-Zikri PNH, Taher M, Susanti D, Ichwan SJA. Cytotoxic activity of Luvunga scandens against human cancer cell lines. Jurnal Teknologi (Sciences \& Engineering). 2016; 78(10): 153-157. [CrossRef]

[11] Ismed F, Devehat FLL, Rouaud I, Ferron S, Bakhtiar A, Boustie J. NMR reassignment of stictic acid isolated from Sumatran lichen Stereocaulon montagneanum (Stereocaulaceae) with superoxide anion scavenging activities. $\mathrm{Z}$ Naturforsch C. 2017; 72 (1-2): 55-62. [CrossRef]

[12] Malhotra S, Subban R, Singh A. Lichens- role in traditional medicine and drug discovery. Internet J Altern Med. 2007; 5 (2): 1-6.

[13] Pejin B, Iodice C, Bogdanovic G, Kojic V, Tesevic V. Stictic acid inhibits cell growth of human colon adenocarcinoma HT-29 cells. Arab J Chem. 2017; 10: S1240-S1242. [CrossRef]

[14] Chahyadi A, Hartati R, Wirasutisna KR, Elfahmi. Boesenbergia pandurata Roxb., An Indonesian medicinal plant: Phytochemistry, biological activity, plant biotechnology. Procedia Chem. 2014; 13: 13-37. [CrossRef]

[15] Ashidi JS, Houghton PJ, Hylands PJ, Efferth T. Ethnobotanical survey and cytotoxicity testing of plants of southwestern Nigeria used to treat cancer, with isolation of cytotoxic constituents from Cajanus cajan Millsp. leaves. J Ethnopharmacol. 2010; 128: 501-512. [CrossRef]

[16] Poerwono H, Sasaki S, Hattori Y, Higashiyama K. Efficient microwave-assisted prenylation of pinostrobin and biological evaluation of its derivatives as antitumor agents. Bioorg Med Chem Lett. 2010; 20: 2086-2089. [CrossRef]

[17] Umehara K, Nemoto K, Kimijima K, Matsushita A, Terada E, Monthakantirat O, Eknamkul WD, Miyase T, Warashina T, Degawa M, Noguchi H. Estrogenic constituents of the heartwood of Dalbergia parviflora. Phytochemistry. 2008; 69: 546-552. [CrossRef]

[18] Hatcher H, Planalp R, Cho J, Torti FM, Torti SV. Curcumin: From ancient medicine to current clinical trials. Cell Mol Life Sci. 2008; 65: 1631-1652. [CrossRef]

[19] Umadevi M, Kumar KPS, Bhowmik D, Duraivel S. Traditionally used anticancer herbs in India. J Med Plant Stud. 2013; 1 (3): 56-74

[20] Mohamed GA, Al-Abd AM, El-halawany AM, Abdallah HM, Ibrahim SRM. New xanthones and cytotoxic constituents from Garcinia mangostana fruit hulls against human hepatocellular, breast, and colorectal cancer cell lines. J Ethnopharmacol. 2017; 198: 302-312. [CrossRef]

[21] Putra DP. 2015. Production of ten marker compounds as standard comparison of Indonesian traditional medicinal plants, Research Report, Andalas University - Department of Health, Republic of Indonesia.

[22] Ismed F. 2014. Production of major constituents of ten 1solation medicinal plants for marker of Indonesian Herbal Pharmacopeia, Research Report, Andalas University, Department of Health Republic of Indonesia.

[23] Putra DP. 2014. Development and production of standardized terpenoid and 1solate compound of iso/deoxyelephantopin from Indonesian traditional medicinal plants Elephantopus scaber (L), Research Report, Andalas University-Department of Health Republic of Indonesia.

[24] Anggia V, Bakhtiar A, Arbain D. Chemical constituents and antibacterial activities of leaves of Sumatran King Fern (Angiopteris evecta G. Forst HOFFM.). Jurnal Farmasi Indonesia. 2015; 7 (4): 195-202.

[25] Ismed F, Farhan A, Bakhtiar A, Zaini E, Nugraha YP, Putra OD, Uekusa H. Crystal structure of olivetolic acid: a natural product from Cetrelia sanguinea (Schaer.). Acta Crystallogr E Crystallogr Commun. 2016; 72 (11): 1587-1589. [CrossRef]

[26] Arbain D, Putra DP. 2016. Simplicia and extract of Stevia Herb (Stevia rebaudiana Bert.), Research Report, Andalas University, Department of Health Republic of Indonesia.

[27] Ismed F, Devehat FLL, Delalande O, Sinbandhit S, Bakhtiar A, Boustie J. Lobarin from the Sumatran lichen, Stereocaulon halei. Fitoterapia. 2012; 83: 1693-1698. 